\title{
Optimalisasi Pendapatan Daerah Melalui Tata Kelola Pendapatan Daerah Satu Pintu
}

\author{
Anshar Maita \\ Sekertariat Daerah Kabupaten Banggai \\ Email: ansharmaita@gmail.com
}

\begin{abstract}
Optimizing regional income through one-stop regional revenue management. The purpose of this study was to determine the optimization of regional income through one-stop regional revenue management. The population in this study is Regional Revenue through One Stop Local Revenue Management. Data collection methods in this study were interviews and documentation. The method of data analysis uses descriptive methods and qualitative methods, namely the analysis of data trigulation. The results of this study indicate that the optimization of regional income through the management of one-stop regional revenue is a solution that must be implemented to avoid and minimize the occurrence of a decrease in PDRD revenue in the management of regional income.
\end{abstract}

Keywords: Regional income, governance, regional income.

\begin{abstract}
Abstrak
Optimalisasi pendapatan daerah melalui tata kelola pendapatan daerah satu pintu. Tujuan penelitian ini adalah untuk mengetahui Optimalisasi pendapatan daerah melalui tata kelola pendapatan daerah satu pintu. Populasi dalam penelitian ini Pendapatan Daerah Melalui Tata Kelola Pendapatan Daerah Satu Pintu. Metode pengumpulan data dalam penelitian ini adalah wawancara dan dokumentasi. Metode analisis data menggunakan metode deskriptif dan metode kualitatif yaitu dengan analisis triamgulasi data. Hasil penelitian ini menunjukkan bahwa optimalisasi pendapatan daerah melalui tata kelola pendapatan daerah satu pintu merupakan solusi yang harus diterapkan untuk menghindari dan meminimalisasi terjadinya penurunan penerimaan PDRD dalam pengelolaan pendapatan daerah.
\end{abstract}

Kata kunci: Pendapatan daerah, tata kelola, pendapatan daerah.

\section{Pendahuluan}

Undang-Undang Nomor 23 Tahun 2014 tentang Pemerintahan Daerah yang ditindaklanjuti dengan PP Nomor 18 Tahun 2016 tentang Perangkat Daerah dimana pembentukannya didasarkan pada asas efisiensi, efektivitas, pembagian habis tugas, rentang kendali, tata kerja yang jelas, fleksibilitas, urusan pemerintahan yang menjadi kewenangan daerah, dan intensitas urusan pemerintahan dan potensi daerah. Peraturan Pemerintah Nomor 18 Tahun 2016 tentang Perangkat Daerah, maka setiap daerah diberikan kewenangan dalam pelaksanaan urusan untuk mengatur daerahnya sendiri.

Kontribusi pajak daerah dan retribusi daerah terbagi dalam kelas rendah pada kisaran lebih kecil dari atau sama dengan $10 \%$, kelas menengah pada kisaran lebih besar $10 \%$ dan dibawah $20 \%$ dan kelas tinggi diatas $20 \%$ terhadap realisasi Anggaran Pendapatan dan Belanja Daerah (APBD) Kabupaten/Kota. Hal ini disebabkan oleh rendahnya basis pajak daerah dan retribusi daerah, peranan PDRD tergolong kecil dalam penerimaan daerah, kemampuan administrasi penagihan dan pemungutan di daerah yang masih rendah dan kemampuan perencanaan, pengembangan serta pengawasan yang lemah. Hal ini disebabkan oleh rendahnya basis pajak daerah dan retribusi daerah, peranan PDRD tergolong kecil dalam penerimaan daerah, kemampuan administrasi penagihan dan pemungutan di daerah yang masih rendah dan kemampuan perencanaan, pengembangan serta pengawasan yang lemah. 
Dinas Kesehatan dengan jenis penerimaan retribusi pelayanan kesehatan, Dinas Lingkungan Hidup berupa retribusi pelayanan persampahan/ kebersihan, retribusi penyediaan dan/atau penyedotan kasus, retribusi uji laboratorium. Dinas PU dan Penataan Ruang berupa retribusi pemakaian kekayaan daerah penyewaan peralatan dan IMB, Dinas Perkimtan berupa retribusi pelayanan pemakaman dan pengabuan mayat serta mobil jenasah. Dinas Perhubungan dengan jenis penerimaan berupa retribusi pelayanan parkir di tepi jalan umum, pengujian kendaraan bermotor, terminal, tempat khusus parkir, pelayanan kepelabuhanan, penyeberangan di atas air, izin trayek dan VIP bandara.

Instansi Sekretariat Daerah dengan jenis penerimaan retribusi tempat penginapan/pesanggarahan/villa dan retribusi izin peruntukan penggunaan tanah/ sewa gedung. Dinas Peternakan dan Kesehatan Hewan dengan penerimaan retribusi rumah potong hewan. Dinas Perikanan dengan retribusi pelelangan ikan, Dinas Perdagangan berupa retribusi pelayanan pasar, izin tempat penjualan minuman keras dan tera ulang. Selanjutnya DPMPTSP dengan retribusi izin gangguan tempat usaha dan retribusi izin usaha perikanan kepada orang pribadi. SATPOL PP dan DAMKAR dengan penerimaan retriubsi pemeriksaan alat pemadam kebakaran. Upaya perbaikan agar pemungutan dan penagihan pajak daerah dan retribusi daerah lebih optimal sehingga mampu memberikan kontribusi yang besar bagi penerimaan daerah. Upaya intensifikasi pajak daerah dan retribusi daerah melalui basis penerimaan, memperkuat proses pemungutan dan penagihan, meningkatkan pengawasan, efisiensi dan perencanaan yang baik perlu dilakukan.

Master Plan ini merupakan penjabaran dari Peraturan Pemerintah Nomor 18 Tahun 2016 tentang Perangkat Daerah yang telah membagi habis tugas kedalam urusan wajib dan urusan pilihan sebagaimana diatur pada pasal 35 dan pasal 37 dimana urusan wajib yang melaksanakan pelayanan dasar dan tidak dasar serta urusan pilihan didasarkan pada potensi daerah, dan merupakan unsur pelaksana yang diwadahi dalam bentuk Dinas. Sedangkan urusan penunjang diatur pada pasal 46 yang melaksanakan urusan untuk menunjang kelancaran fungsi pelaksana (inti) dan diwadahi dalam bentuk Badan.

Selaras dengan uraian diatas, struktur organisasi yang terdapat dalam Peraturan Menteri Dalam Negeri Nomor 5 Tahun 2017 tentang Pedoman Nomenklatur Perangkat Daerah Propinsi dan Daerah Kabupaten/Kota yang Melaksanakan Urusan Penunjang telah memberikan gambaran terhadap Optimalisasi Pendapatan Daerah yang tidak tumpang tindih dimana unsur pelayanan wajib dasar dan tidak dasar serta pilihan melaksanakan urusan penunjang. Tumpang tindih ini terjadi di daerah yang masih memberlakukan Peraturan Daerah dengan memakai konsideran UU 32 Tahun 2004 tentang Pemerintahan Daerah.Olehnya itu secara maksimal penyusunan Master Plan tentang Optimalisasi Pendapatan Daerah Melalui Tata Kelola Pendapatan Daerah Satu Pintu akan memberikan arah bagi daerah guna mengoptimalisasikan tujuan, alternatif keputusan, pengembangan sumber daya yang dibatasi sehingga terwujud optimalisasi penerimaan sesuai dengan perencanaan yang dilakukan secara efisien, efektif dan transparan untuk meningkatkan pendapatan daerah dimana semua jenis penerimaan daerah yang merupakan bagian dari pendapatan daerah dikelola oleh Badan Pendapatan Daerah. 


\section{Literature Review}

\subsection{Pengertian Optimalisasi}

Optimalisasi adalah suatu proses untuk mencapai hasil yang ideal atau optimal (nilai efektif yang dapat dicapai). Optimalisasi adalah proses pencarian solusi yang terbaik, tidak selalu keuntungan yang paling tinggi yang bisa dicapai jika tujuan pengoptimalan adalah memaksimumkan keuntungan, atau tidak selalu biaya yang paling kecil yang bisa ditekan jika tujuan pengoptimalan adalah meminimumkan biaya Optimalisasi adalah proses pencarian solusi yang terbaik, tidak selalu keuntungan yang paling tinggi yang bisa dicapai jika tujuan pengoptimalan adalah memaksimumkan keuntungan, atau tidak selalu biaya yang paling kecil yang bisa ditekan jika tujuan pengoptimalan adalah meminimumkan biaya. Solomon (2016) mendefinisikan optimalisasi adalah prestasi kerja yang dicapai dari target yang telah ditetapkan atau melampaui standar kerja dan Satria (2017) mengemukakan optimalisasi adalah suatu keadaan yang cenderung mendorong kepada peningkatan yang lebih tinggi dari kondisi sebelumnya. Maka dapat disimpulkan bahwa optimalisasi merupakan sebuah proses untuk mencari metode atau cara yang paling baik dari sebelumnya. Dalam konteks ini optimalisasi diharapkan dapat meningkatkan penerimaan daerah dengan metode atau cara yang baru.

\subsection{Konsep Pendapatan Daerah}

Pendapatan daerah merupakan salah satu sumber penerimaan daerah. Pada Ketentuan Umum Peraturan Pemerintah Nomor 12 Tahun 2019 tentang Pengelolaan Keuangan Daerah menyebutkan bahwa penerimaan daerah adalah urang yang masuk ke kas daerah. Pendapatan Asli Daerah (PAD) meliputi pajak daerah, retribusi daerah, hasil pengelolaan kekayaan daerah yang dipisahkan, dan lain-lain pendapatan asli darah yang dipisahkan. Jenis pajak daerah dan retribusi daerah wajib mendasari Undang-Undang Nomor 28 Tahun 2009 tentang Pajak Daerah dan Retribusi Daerah. Pendapatan lain-lain yang sah meliputi hibah, dana darurat dan lain-lain pendapatan sesuai ketentuan peraturan perundang-undangan. Hibah yang dimaksud berupa bantuan uang, barang, dan atau jasa yang berasal dari pemerintah pusat dan pemerintah daerah lain. Implementasi dari optimalisasi pendapatan daerah menjadi suatu modal dasar pemerintah daerah dalam mendapatkan dana pembangunan dan memenuhi belanja daerah, sehingga memperkecil tingkat ketergantungan dalam memperoleh subsidi dari pemerintah pusat.

\subsection{Konsep Penerimaan Satu Pintu}

Penerimaan Satu Pintu merupakan sebuah konsep yang bertujuan untuk mengoptimalkan pendapatan daerah pada semua jenis penerimaan pendapatan daerah berdasarkan Pasal 30 Peraturan Pemerintah Nomor 12 Tahun 2019 tentang Pengelolaan Keuangan Daerah. Mewujudkan pelaksanaan tata kelola pendapatan daerah melalui penerimaan satu pintu, maka ada beberapa variabel yang menjadi pertimbangan secara langsung dan tidak langsung. Hasil yang diharapkan adalah tercapainya peningkatan kinerja yang jelas dan terukur dalam hal realisasi pendapatan sesuai indikator kinerja pada masing-masing jabatan. Sumber daya aparatur pemerintahan berupa administrasi pendapatan daerah berbasis teknologi informasi, peningkatan kinerja pelayanan public. Modul standarisasi meliputi standar pelayanan administratif, petunjuk pelaksanana penerbitan dokumen pajak dan retribusi daerah serta mempermudah penyusunan SOP. 


\subsection{Solusi Penanganan Dalam Peningkatan Pendapat Daerah}

Persoalan kebocoran ini telah menjadi budaya yang sangat mengakar dalam birokrasi, sehingga sangat sulit untuk diberantas habis tanpa ada jurus-jurus yang benar untuk mengatasinya. tata kelola pendapatan satu pintu yang pengoperasionalannya dilakukan melalui penggunaan teknologi berbasis aplikasi yang dapat menyimpan semua database registrasi, laporan, komplain dan berbagai risalah-risalah yang terkait dengan pengelolaan sumber penerimaan dari berbagai sektor yang dikelola oleh Dinas dan Badan yang mengelola penerimaan pendapatan daerah. Aktivitas pelayanan dan meminimalisasi terjadinya pertemuan secara langsung (face to face) antara pihak subjek yang dipungut dengan pihak petugas pemungut serta memaksimalkan aktivitas transaksi penggunaan pembayaran non tunai untuk menghindari praktek korupsi.

\subsection{Struktur Organisasi}

Pedoman organisasi yang terkait dengan pengelolaan pendapatan daerah kabupaten / kota utamanya mengacu pada Peraturan Pemerintah Nomor 18 Tahun 2016 Tentang Perangkat Daerah dan Peraturan Menteri Dalam Negeri Nomor 5 Tahun 2017 Tentang Pedoman Nomenklatur Perangkat Daerah Provinsi dan Daerah Kabupaten / Kota yang Melaksanakan Fungsi Penunjang. Perumusankebijakanteknisperencanaandan pengembangan pendapatan daerah, serta intensifikasi pajak daerah dan retribusi daerah. Melakukan analisis regulasi pendapatandaerah dan merumuskan standarisasi kebijakan operasional prosedur, serta perumusan kebijakan tentang sistem administrasi pelayanan pajak daerah. Perumusan kebijakan teknis pengendalian dan evaluasi pendapatan daerah, standar operasional prosedur.

\section{Kesimpulan}

Undang Undang Nomor 23 Tahun 2014 tentang Pemerintahan Daerah dan Peraturan Pemerintah Nomor 18 Tahun 2016 tentang Organisasi Perangkat Daerah, telah memberikan kewenangan dan urusan yang lebih luas kepada Pemerintah Daerah terutama dalam mengatur daerahnya sendiri. Pemerintah Daerah diberi kewenangan untuk menggali sumber-sumber dana yang ada sesuai potensi yang dimilikinya sehingga dapat meningkatkan Pendapatan Asli Daerah terutama dari pajak daerah dan retribusi daerah, untuk membiayai urusan penyelenggaraan pemerintahan dan untuk memenuhi kebutuhan daerahnya sendiri. Hal ini disebabkan dengan berbagai permasalahan sehingga daerah belum optimal dalam melakukan pemungutan dan penagihan pajak daerah dan retribusi daerah. Permasalahan yang paling utama adalah masih rendahnya kesadaran masyarakat dalam melaksanakan kewajiban PDRD dan rendahnya kompetensi dan komposisi aparatur di daerah, selain itu masih ada ketimpangan pajak antara pemerintah pusat dan daerah yang tercermin dari jumlah penerimaan pajak daerah baik propinsi maupun kabupaten/kota.

Berdasarkan uraian sebelumnya, maka disimpulkan bahwa optimalisasi pendapatan daerah melalui tata kelola pendapatan daerah satu pintu merupakan solusi yang harus diterapkan untuk menghindari dan meminimalisasi terjadinya penurunan penerimaan PDRD dalam pengelolaan pendapatan daerah, dengan memberikan penguatan dan perbaikan pada:

1. Undang Undang Nomor 28 Tahun 2009 tentang Pajak Daerah dan Retribusi Daerah yang mengatur kewenangan daerah untuk melakukan pemungutan / penagihan pajak daerah dan retribusi daerah pada beberapa jenis penerimaan yang bersumber dari pajak daerah dan retribusi daerah agar diganti dengan undang undang yang baru sesuai dengan semangat dan makna Undang Undang 23 Tahun 2014 tentang Pemerintahan Daerah. 
2. Kebijakan yang berkaitan dengan Peraturan Pemerintah Nomor 12 Tahun 2019 tentang Pengelolaan Keuangan Daerah untuk mengatur mengenai perencanaan dan penganggaran, pelaksanaan dan penatausahaan, serta pertanggungjawaban keuangan daerah agar disesuaikan kembali sesuai dengan urusan penyelenggaraan pemerintahan daerah dan kepentingan daerah.

3. Penguatan Peraturan Pemerintah Nomor 18 Tahun 2016 tentang Perangkat Daerah di mana pembentukannya didasarkan pada asas efisiensi, efektivitas, pembagian habis tugas, rentang kendali, tata kerja yang jelas, fleksibilitas, urusan pemerintahan yang menjadi kewenangan daerah dan intensitas urusan pemerintahan dan potensi daerah.

4. Memperkuat proses pemungutan/penagihan dengan mempercepat penyusunan Perda/Perbup terkait PDRD serta mengubah tarif yang sudah tidak sesuai lagi dengan perkembangan ekonomi masyarakat serta perbaikan sistem kerja yang berbasis non tunai dan on line sistim aplikasi, di mana semua aktivitas penerimaan daerah harus terintegrasikan dalam sistem digitalisasi database satu pintu.

5. Memperkuat pengawasan dan evaluasi di dalam menangani permasalahan optimalisasi yang diidentifikasi berdasarkan tujuan, alternatif keputusan dan sumber daya yang dibatasi dengan melakukan pemeriksaan secara berkala, memperbaiki proses pengawasan, menerapkan sanksi terhadap penunggak pajak, meningkatkan pembayaran pajak dan pelayanan yang diberikan oleh daerah.

6. Meningkatkan efisiensi administrasi dan menekan biaya pemungutan/penagihan dengan memperbaiki prosedur adiministrasi PDRD melalui penyederhanaan administrasi dan meningkatkan efisiensi pemungutan/penagihan dari setiap jenis penerimaan serta melakukan perencanaan perpajakan yang lebih baik dengan meningkatkan koordinasi dengan Organisasi Perangkat Daerah dan Instansi terkait.

\section{Daftar Pustaka}

Hadipraja, Harto, 2015. Optimalisasi sebagai Suatu Konsep Hasil Kerja. Penerbit Tarsito, Bandung.

Halim, Abdul, 2016. Manajemen Keuangan Daerah. Bunga Ramai, Penerbit UPP AMP YKPN, Yogyakarta

Handoyo, Djafar, 2015. Pengelolaan PAD dan Keuangan Daerah. Penerbit Remadja Rosdakarya, Bandung.

Kaho, Riwu Josep, 2013. Prospek Otonomi Daerah di Negara Republik Indoensia. PT. Raja Grafindo Persada, Jakarta.

Keputusan Menteri Dalam Negeri Nomor 270/10190/SJ tanggal 2 Oktober 2019 tentang Kesepakatan dalam Mendukung Program Koordinasi dan Supervisi Pencegahan Korupsi Melalui Tata Kelola Pendapatan Daerah Satu Pintu.

Khaimuddin, Zaki, 2016. Optimalisasi: Teori dan Praktek. Penerbit Rineka Cipta, Jakarta.

Kunarjo, 2015. Perencanaan dan Pembiayaan Pembangunan. Universitas Indonesia, Jakarta.

Mahdi, Maputra, 2015. Perencanaan Dalam Organisasi Pemerintah. Penerbit BPFE, Yogyakarta.

Mardiasmo, 2016. Otonomi dan Manajemen Keuangan Daerah. Penerbit Andi, Yogyakarta.

Martopo, Hasan, 2014. Pendapatan Asli Daerah. Penerbit Gunung Agung, Jakarta.

Soedarsono, 2015. Optimalisasi dalam Kinerja Kerja. Penerbit Liberty, Yogyakarta.

Solomon, Satter, 2016. The Optimization Concept in Good Governance. Prentice Hall, Ohio University, USA.

Peraturan Pemerintah Nomor 18 Tahun 2016 tentang Perangkat Daerah. 
Permendagri Nomor 5 Tahun 2017 tentang Pedoman Nomenklatur Perangkat Daerah Provinsi dan Daerah Kabupaten/Kota.

Peraturan Pemerintah Nomor 12 Tahun 2019 tentang Pengelolaan Keuangan Daerah.

Undang-Undang Nomor 23 Tahun 2014 tentang Pemerintahan Daerah.

Undang-Undang Nomor 28 Tahun 2009 tentang Pajak Daerah dan Retribusi Daerah.

\section{Copyright Disclaimer}

Copyright for this article is retained by the author(s), with first publication rights granted to the journal. 